\title{
OMURGA VE SANAT
}

\section{Erol KILIÇ ${ }^{1}$, Süleyman ÖZDERİN ${ }^{2}$}

\begin{abstract}
ÖZ
Canlı organizmaların anatomik yapısını ve organik bütünlüğünü oluşturan en temel yapı elemanı taşıdıkları omurgalarıdır. Vücudun iskelet yapısını omurga oluşturur. İskeleti oluşturan bütün yapı elemanları omurgaya bağlı olarak, omurganın yapısına göre biçimlendirilmişlerdir. Omurgayla tam bir uyum sağlarlar. Fonksiyonel iliş̧ileri de organik bir bütün içinde devam eder.Sanat yapıtları da tıpkı organizmalar gibi organik bir bütünlük gösterirler. Her sanat yapitı onu oluşturan ana eksen üzerinde gelişir. $\mathrm{Bu}$ eksen sanat yapıtının omurgasıdır. Sanat yapıtında komposizyonu oluşturan diğer elemanlar bu eksene göre uyum içimde kompoze edilir. $\mathrm{Bu}$ nedenle sanat yapıtıyla omurga arasında kavram olarak sıkı bir ilişki vardır. Omurga aynı zamanda sanatçıların esinlendiği, onları etkileyen plastik forma da sahiptir. Omurgayı oluşturan omurlar üst üste ya da yan yana dizilerek muazzam bir tasarım oluştururlar. Modüler bir yapı oluşturması nedeniyle bir çok mimara tasarımcıya, heykeltraşa ve ressama ilham kaynağı olmuştur. Bu çalışma yukarda sözü edilen kavramlar üzerine ele alınmış; omurganın resimle, heykelle, mimarlıkla ve endüstriyel tasarımlarla olan ilişkisi başlıklar halinde örnek verilerek çözümlenmeye çalışılmıştır.
\end{abstract}

Anahtar Kelimeler: Omurga ve sanat, Omurga ve heykel, Omurga ve resim, Omurga-mimari, Omurga-form iliş̧isi

\footnotetext{
${ }^{1}$ Prof. Dr.,Gelişim Üniversitesi Uygulamalı Bilimler Yüksek Okulu Restorasyon ve Konservasyon Bölümü, İstanbul, ekilicerol(at)gmail.com

${ }^{2}$ Öğretim Görevlisi, Dr., Akdeniz Üniversitesi Güzel Sanatlar Fakültesi Grafik Bölümü, selekant(at)gmail.com
} 


\title{
SPINE AND ART
}

\begin{abstract}
The most basic structure that constitutes the anatomical structure and organic integrity of living organisms is the vertebrae which they carry. Skeletal structure of the body is thebackbone. All the component parts constituting the skeleton are for med according to the structure of thespine, depending on the vertebral body. They fit in perfectly with the spine. Functional relationships also continue as an organic whole. Art works, like organisms, show an organicunity. Eachwork of art evolves on its main axis. This axis is the backbone of artwork. The other elements composing the composition in the artwork are composited according to this axis. For this reason, there is a close relationship between the artwork and the spine as a concept. The spine also has a plastic form inspired by the artists and influencing them. The vertebrae that form the vertebrae are stacked vertically or side by side to form an enormous design. Due to its modular structure, many architects have been inspired by designer, sculpture and art.This study focuses on the above mentioned concepts; It has been tried to analyze the sampling of the spine in relation to paintings, sculptures, architectural and industrial designs.
\end{abstract}

Keywords: Spineand art, Spineandsculpture, Spineandpainting, Spinearchitecture, Spine-form relationship.

Kılıç, Erol ve Özderin, Süleyman. “Omurga ve Sanat”. ulakbilge 5.18 (2017):1949-1967 1967.

Kılıç, E. ve Özderin, S. (2017). Omurga ve Sanat. ulakbilge, 5 (18), s.1949- 


\section{OMURGANIN PLASTIZMI VE SANATLA İLİŞKISİ}

\section{1-Giriş:}

İnsanoğlu dahil olmak üzere omurga; doğada var olan bir çok canlıyı ayakta tutan, onların yaşamsal hareketlerini birinci derecede etkileyen bir sistemin en önemli parçalarından birdir. Omurga, iskeleti olan tüm canlılarda, iç ve dış yapısıyla daima merkezi bir konumdadır. Omurganın merkezi anlamda biçimsel özellikleri, sistemin taşıyıcısı olması, bilimsel ve sanatsal çalışmalarda insanın doğayı gözlemlemesinden elde ettiği çıkarımların en büyük ürünüdür. Bu yönüyle omurga sisteminin doğada varoluş biçimi; bilimsel ve sanatsal ürünlerin de kendi mekanikleri içerisinde işleyiş biçimi olarak keşfedilir. Bu makalede omurga sisteminin bir tasarım mantığı olarak insanın meydana getirdiği çeşitli ürünlere yansıma biçimleri incelenecektir. Omurga yapısının sahip olduğu biçimsel mantık insanın yaşamında yer alan bir çok tasarım ürününün de biçimsel mantığı olarak gerçekleştirilir. Dolayısıyla iç organlarımızın asıldığı bir askı ipi görevi olan omurganın ayakta durmamızı sağlayan fonksiyonel bir görevi olduğu gibi, organik yapısı ve parça bütün ilişkisi bakımından da son derece estetik bir görünüme sahiptir. Dik duruşta dengenin korunabilmesi için öne ve arkaya doğru kıvrımlar yapan omurga, 'S' şeklini andıran bir forma sahiptir ve birbirlerine bağlı omurlardan oluşmaktadır. Omurgayı oluşturan omurlar fonksiyonel işlevlerine göre muntazam bir estetik yapıya sahiptir.

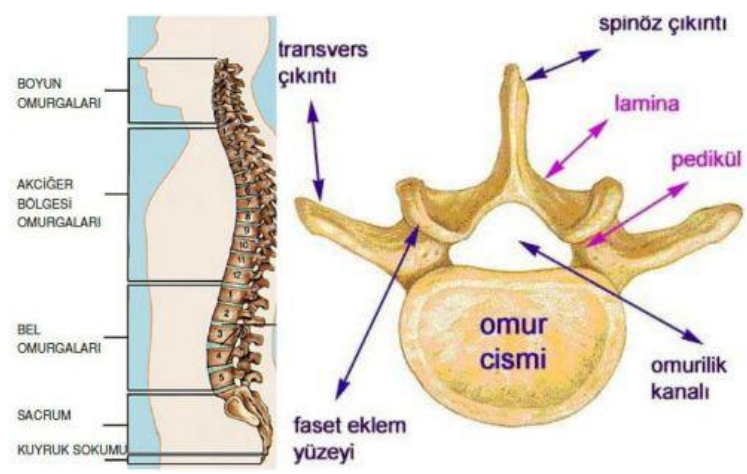

Görsel-1. Omurga ve Omur

Yaklaşık olarak $70 \mathrm{~cm}$. uzunluğu ve birbirine eklenmiş 33 omurdan oluşan yapısıyla, iskeletimizin temel eksenini oluşturan omurgamız, çok kuvvetli bir destek olmasına rağmen, aynı zamanda eğilebilen esnek bir yapıdadır. Omurga oldukça 
sağlam olan maddi yapısı ile toplumsal yaşam içerisinde manevi olarak sahip olduğumuz duruşun da onursal bir temsilcisidir. Toplumsal yaşamda bireysel olarak sahip olduğumuz karakteristik özellikler "omurgalı..." veya "omurgasız..." deyimlerle nitelenirken, yaşadığımız olaylar içerisinde bizim için gurur meselesi olabilecek bir takım etik değerlendirmelere de mutlaka konu oluruz. Bu bağlamda manevi olarak sahip olduğumuz "omurga" ne kadar sağlam olursa, bunu temsil eden onurumuz da ruh dünyamıza bir o kadar sağlıklı katkılarda bulunacaktır. Sağlıklı bireyler olarak ihtiyaç duyduğumuz bu değerler sadece bizim kültürümüzde önemsenmiyor. Örneğin bize en yakın, Azerice'de omurga yerine halen kullanılmakta olan "onurga" sözcüğü, belki bir anlamda insan varlığı içinde kemikleşmesi beklenen değerleri ifade eder. Onurumuzun omurgamız üzerinde yükseldiğini ifade etmek için günümüzde bu ifadeler sıklıkla kullanılır. "Omurgalı insan" (değer yargıları ile bütünleşen insan anlamına gelen) değimi onurlu duruşu ifade etmek için de kullanılan bir söylemdir.

Homo Sapiens/Bilen İnsan'in evrimsel atası olarak kabul edilen Homo Erectus/Dik Duran İnsan'dan bu yana, yaklaşık 1,9 milyon yıldır en belirleyici özelliğimiz omurgamızdan yansır: Dik durmak. Onurunu korumak üzere ölümü göze alan Sokrates'in son sözlerini Platon şöyle aktarır: "Asklepios'a bir horoz borçluyum”. Doğan güneşin habercisi, uyanıklığın simgesi horoz, Antik Yunan geleneğinde şifaya kavuşanlar tarafından adanırdı. Nihai şifaya ölümüyle kavuştuğuna inanan Sokrates, etik olarak omurgalı bir insan olduğunu bize kanıtlamış; onuru omurgası üzerinde yükselecek nesillere örnek olmuştur (March, s.139-140, 2001).

Davranışlarımızdaki bütünlüğü ve değer yargılarımızdaki bütünleşmenin ifadesi olarak kullanılan omurganın plastik sanatlarla ve mimariyle sıkı bir ilişkisi vardır. Aslında, omurga kavram ve taşıdığı anlam olarak bütün sanatlarda karşılığını bulan bir kavramdır. Bir şiirin, roman ya da öykünün, bir senaryonun, bir bestenin kurgusunda mutlaka ana bir omurga vardır. Ana omurgaya göre roman ve öyküde olaylar gelişir, şiirde ana temaya göre sözcükler düzenlenir ve ritim oluşturulur, müzikte ana ritme göre notalar düzenlenir. Omurganın sanatla olan ilişkileri resim, heykel, mimari ve endüstriyel ürün tasarımlarında görebilir. Doğanın varoluş formlarının temel sistemi olan omurga, elbette insan faktörünün doğal ürünü olan sanat ve tasarım ürünlerinde de aynı var oluş sistemine göre uygulanacaktır.

\section{2-OMURGA VE RESIM}

Resim sanatı tarihinde ilk defa bir sanatçı (ressam) insan anatomisinin iç yapısıyla üzerinde son derece ayrıntılı bir yaklaşımla çalışıyor. Bu sanatçı büyük dahi Rönesans'ın en önemli ustalarında olan Leonardo Da Vinci'dir. Leonardo Da 
Vinci yalnızca usta bir ressam değil, aynı zamanda mühendislik, doğa bilimleri, felsefe ve tıp alanında insan anatomisi ile ilgili tasarım ve çizimleri ile olağanüstü çalışmalar yapan eşsiz bir sanatçı ve bilim insanıdır. Dehanın tartışılmaz temsilcisi olan sanatçı, canlı olarak gerçekleştirdiği çizimlerde omurga temelinde, iç organlar dahil olmak üzere kas ve iskelet sistemini de tüm yönleriyle tespit etmiştir.
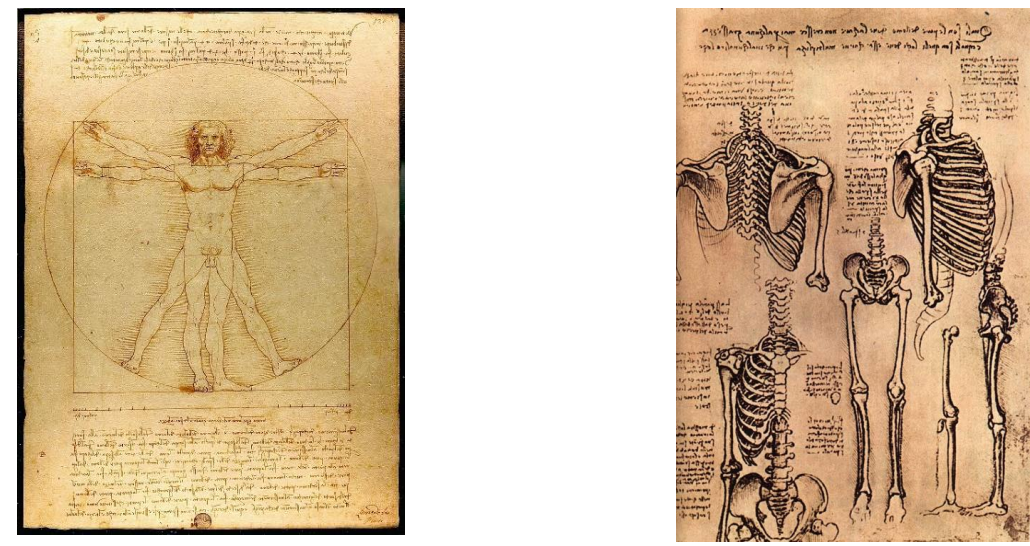

Görsel-2. Leonardo-Da-Vinci Vinci, Vitruve, Luc, Viatour.Görsel-

\section{Leonardo-Da-Vinci-Bones.}

Görsel-2'de görülebileceği gibi, Da Vinci insan anatomisi üzerinde ciddi gözlemler yaparak ideal bir insanın orantıları ile ilgili bilgiler verir. İnsan anatomisinin oranları arasında altın kesit oranlarının bulunduğunu gösterir. Altın oran, göze hoş gelen en mükemmel orandır. "Biz insanı en güzel şekilde yarattık"(Tin, 95/4) ayetiyle örtüşen bir durumdur. Da Vinci bunu kare ve onun asal temeli olan daire ile ilişkilendirerek, insanı evrenin merkezine koyar. İlahi mertebede insanoğluna biçilen değer; " $O$ (Allah) ki, yeryüzünde her şeyi sizin için yarattı..." (Bakara, 2/29) ayetiyle de örtüşen bir durumdur. Rönesans'ın bu dahi ustası bununla da yetinmez, engizisyonun bütün baskılarına rağmen geceleri mezardan gizlice çıkardığı kadavralar üzerinde de araştırmalarını sürdürür. İskelet yapımızı oluşturan omurga, kaburgalar ve kemiklerle ilgili gözlemler yaparak, onların resimlerini betimler, organların yapısıyla ilgili görsel bilgiler de sunar. $\mathrm{Bu}$ betimlemeler bize şu mesajları verir: Görünen dış bedenin asıl yapısını iç yapının şekillendirdiği bilgisi, sanatçıları bunun üzerinde düşünmeye davet eder. Görünen dış gerçeğin yanında bizi iç gerçeği görmeye davet eder. Böylelikle de gerçeklik duygumuzu sorgular. İnsan anatomisi ile omurga arasında bağlantılar kurmamızı 
sağlar. Omurga ile sanat arasında sıkı bir ilişkinin varlığını ortaya koyar. Omurları çizimlerle tek tek betimleyerek, onların bir mühendislik şaheseri olarak bedenin içerisinde nasıl konumlandığını görmemizi sağlar. Bunların tamamı ancak bir dahinin yapacağı işlerdir. Da Vinci yalnızca insan anatomisi üzerinde araştırma yapmamış, hayvan kadavraları üzerinde de incelemeler yaparak, onların formlarını betimlemiştir.
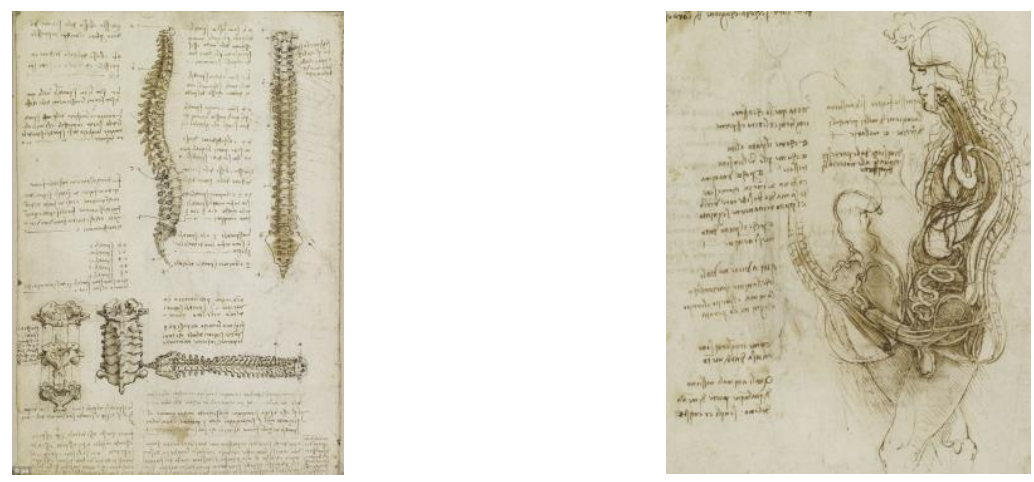

Görsel-4, 5. Leonardo Da Vinci, (sağ) Omur ve Omurga Çizimleri, (sol) İç Organların Naasıl Çalıştı̆̆ını Gösteren Çizimleri

Leanorda Da Vinci'nin maddenin görünen gerçekliği ile birlikte iç gerçekliği ile olan araştırmaları 19. yüzyılın sonları ve 20. yüzyıl başlarında sanatın soyuta doğru evrilmesinde sanatçılara yeni gerçekliğin kapılarını aralayacak ve Da Vinci'den aldıkları ilhamla içsel gerçekliğe yöneleceklerdir. 20. yüzyılın ikinci yarısından sonra plastik sanatlarda bir çok sanatçı bireysel üsluplarını oluşturmada organik varklıların strüktürel yapılarından ilham alarak, resimler, seramik eserler ve heykeller üretilmiştir. Örneğin Amerika'lı sanatçı Alex 'Triglas Deep Spine' adını verdiği bir dizi resimler yapmıştır. (Görsel-6) Tuval üzerine akrilikle gerçekleştirdiği bu resimde süngerimsi dokuların yer aldığı renk ve lekeler kemiklerin süngerimsi dokusunu çağrıştırmaktadır. Resim yüzeyinin sağ üst tarafına ise omurgayı sembolik olarak soyut biçimle betimlemiştir.

Koreli sanatçı Sara Yong ise Görsel-7'de geometrik biçimle içinde resmin imgesi olarak omurgayı betimlemiş ve omurgayı resmin merkezine koymuştur. Geometrik soyut biçimler üzerinde yer yer dokusal etkiler oluşturarak resmin organik bütünlüğünü sağlamaya çalışmıştır.

Günümüz Amerika'lı ressamlarından Noelle Rollin'in 'Spine' adlı resminde omurilikten bir bölümü resmin ana teması olarak dışavurumcu renklerle 
betimlemiştir. (Görsel-8) Royal Mire 'Spine' adını verdiği resimde organik formlarla figürleri birlikte kompoze ederek, resmin merkezine omurgay1 yerleştirerek resmin organik bütünlüğününü sağlamaya çalışmıştır. Figüratif unsurları soyut unsurlarla buluşturarak, gerçek ve soyut arasında bir ilişki kurmaya çalışmıştır. (Görsel-9).
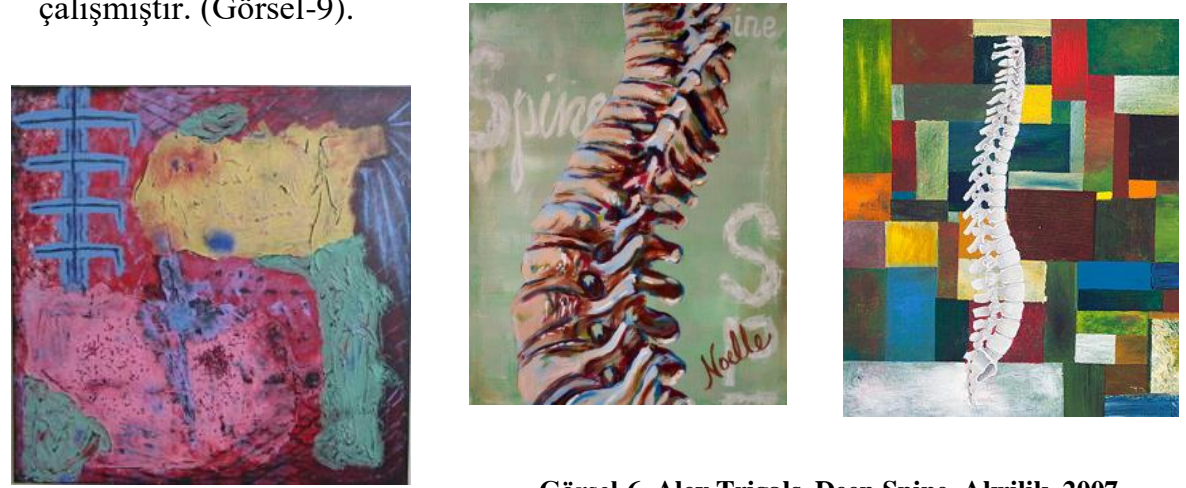

Görsel-6. Alex Trigals, Deep Spine, Akrilik, 2007.

Görsel-7. Sara Young, Spine, 2011, Akrilik.

Görsel-8. NoelleRolli,Spine,2010

'The Spine of the Matter' adını verdiği resminde Robert Sofian omurgadan esinlenerek soyut bir biçim oluşturmuştur. İlk bakışta bir omurga formu olduğu anlaşılan bu resim form leke ve dışavurumcu renklerle soyutlaştırılmıştır. (Görsel10)
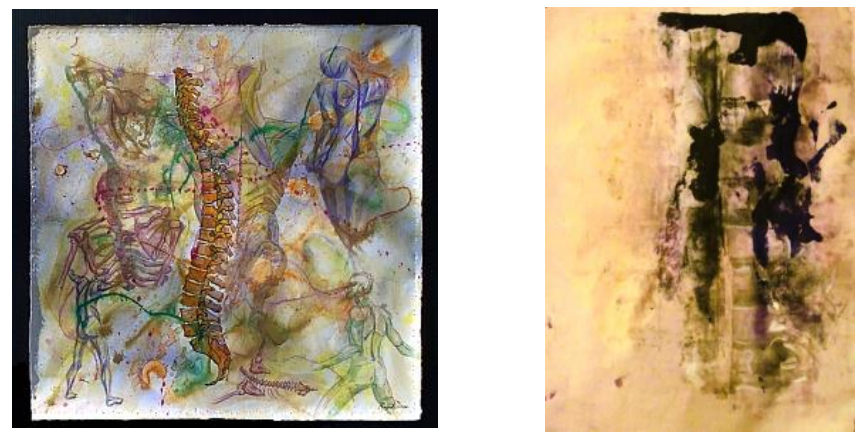

Görsel-9. Royal Mire, Spine, Suluboya, 2005, 30x30cm.

Görsel-10. Robert Sofian,The Spine of the Matter,Akrilik. 


\section{3-OMURGA VE HEYKEL}

Modern sanatın ortaya çıkışına kadar insan bedeni neredeyse heykel sanatıyla özdeşleşmiş ve sanatın en önemli yaratma konularından biri olmuştur. Bu özel ilişki içinde "beden imgeleri” eski çağlarda yapıldığı dönemlerin düşünce ve ruhsal yaşamını en iyi yansıtan sanat yapıtları olmuştur. Geleneksel sanat içinde beden estetiği heykelin var oluş biçimini de belirlemiştir. Güç, kahramanlık, büyü, erdem ve yücelik gibi değerler beden üzerinden anlatılmakta ve ölümsüzleşmekteydi. Günümüz müzelerinde bununla ilgili pek çok heykel örneği görülebilir.

Modern sanatın ortaya çıkmasıyla 19. yüzyılın sonlarına doğru sanat yapıtları beden estetiği üzerinde büyük bir değişikliğe neden olmuş ve geleneksel anlayışta yapılan beden tasvirlerinden ayrılmaya başlamıştır. Özellikle 20. yüzyılın başlarında sosyo-kültürel alanda gelişmeler sanatçılara öncü bir rol de yüklemiş ve bu rol geleneğe karşı radikal sonuçlara yol açmıştır. Yaşamın hemen her alanında, dönemin genel karakterine uygun olarak sanatçının özgürlüğü artmış ve söz konusu radikal değişimler yeni beden algısına değişken biçimlerde yansımıştır. İnsan bedeni ve canlı organizmaların fiziki yapısı temel alarak soyutlaşan heykel sanatı, resim dilinde olduğu gibi soyutlama yoluyla biçimsel yenilikleri heykel diline kazandırmıştır. Bunun en somut örnekleri Henri Moore ve çağdaşlarında görülebilir. 20. yüzyılın öncü sanatçılarından birisi olan Henri Moore'un sanatında yarattığı imgeler yaşam ve insan merkezlidir. Beden imgelerinin bazıları neredeyse soyutlamanın sınırlarını aşmış ve soyutluk sınırına dayanmıştır. Parçalanmış bedensel kütleler, soyutluk durumuna erişerek, doğal güçlerinin biçimlendirdiği görünümler hissini de uyandırır (Y1lmaz,s.53, 2016).

Görsel-11'de, Moore'un bu eserinde beden parçaları dahi soyutlaşmış parçalara ayrılmış organik kütlesel şekillere dönüşmüştür. Eserde görülen parçalar omurgayı oluşturan omurlarla benzemektir. Başta insan olmak üzere organizmaların parçaları soyut biçimlerle benzerlik taşırlar. Bir çok heykeltraş soyut biçimleri tasarlarken organizmaları oluşturan parçalardan esinlenmektedir. 

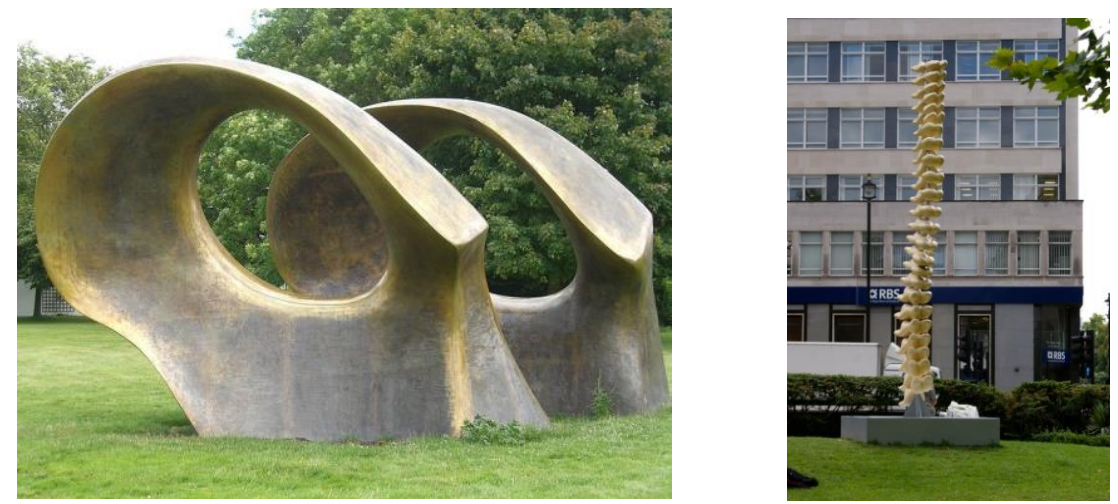

Görsel-11. HenriMoore.Görsel-12. Peter Kristiansen, GiantSpineSculpture.

Günümüz sanatçılarından da bu tür yaklaşımlarla çalışan pek çok örnekler verilebilir. Görsel-12'de Peter Kristianen 'GiantSpineSculpture' adını verdiği soyut heykeli omurları andıran formları üst üste dizerek tasarlamıştır. Burada modüler bir tasarım söz konusudur. İnsanın kendisi dik duran bir omurga ile temsil edilmektedir. Her şeye rağmen dik durabilen bir insan.

Güney Kore'nin başkenti Seul'da dünyaya gelen Choe, kinetik heykel çalışan çağdaş bir sanatçıdır (Ravling, s.5, 2008). Dedesi otomobil tasarlayan bir bilim adamı, ayrıca anne ve babası da heykeltraşdı.
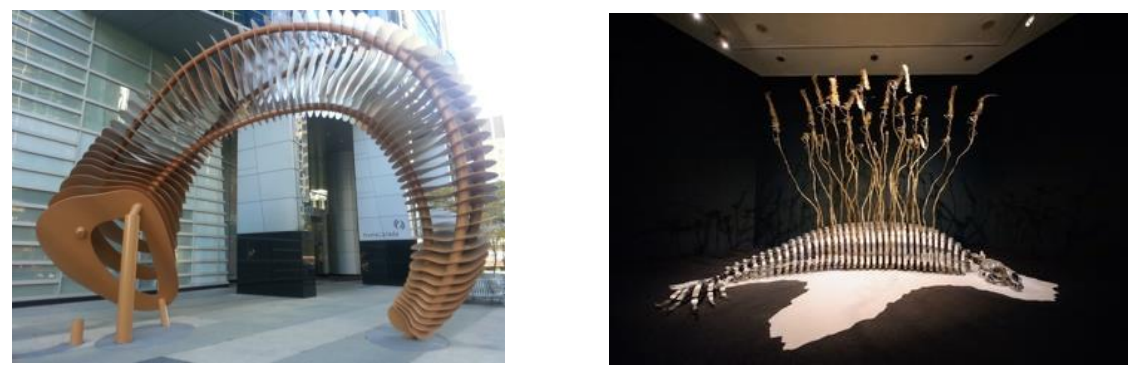

Görsel-13. SpineandPanels, Dovntown Art Guide, 1910. Görsel-14.Choe U-Ram, Guardian of the Hole, 2011, MetalikCalgary, Kanada Materyal, Reçine, Moto, Dişli, LED. 
Kinetik heykelleri ile ünlü olan günümüz sanatçısı Choe'nin heykellerinin hikayesi vardır. Görsel-15'de, 'Guardian' adlı heykel bir arada yaşamanın sembolüdür. Choe, Asia Society ile yaptı̆̆ 1 bir röportajda "Yaşam döngüsü ve evrenin tarihini hissetmek ve göstermek istedim. Benim için ilginçti, eski mitolojilerdeki metaforlar hala modern toplum için geçerli" demektedir(asiasocety.org). Görsel-14 ve $15^{\prime}$ 'de bulunan heykellerin canlı organizmaların omurga yapısından esinlenerek tasarlandıkları açıkça görülmektedir.

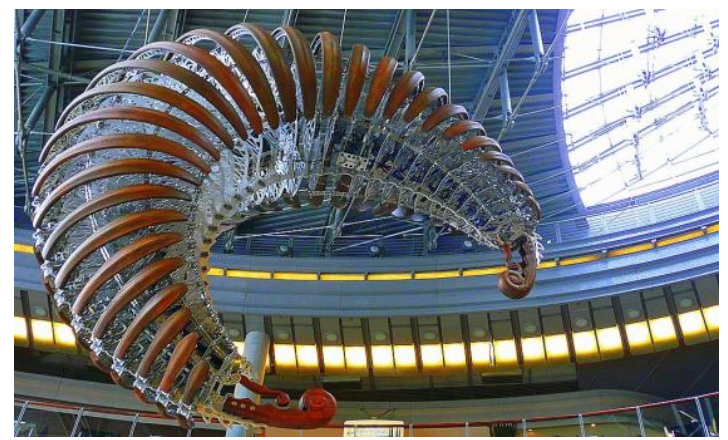

\section{Görsel-15. U-Ram Choe,OpertusLunulaUmbra (HiddenShadow of Moon), 2008Bitforms} Gallery.

Omurga yapısı yabancı sanatçılarda olduğu gibi Türk sanatçıları arasında da sıklıkla ele alınmıştır. Bu konuda çalışmaları bulunan Kemal Tufan; 1962 Yılında İstanbul Silivri'de doğdu, 1985 yılında mezun olduğu İstanbul Teknik Üniversitesi Endüstri Mühendisliği bölümünden sonra, Mimar Sinan Üniversitesi Heykel bölümüne girerek hayatının yönünü değiştirdi. Kemal Tufan doğal taşlar, su, video, fotoğraf gibi farlı öğeleri bir arada kullanarak gerçekleştirdiği heykel, video-heykel ve enstelasyonlarıyla çok yönlü yaklaşımını sanatsal nesnelere dönüştürmektedir. Tufan'ın heykelleri, bir kütlede sağlı sollu simetrik çıkıntılarla tasarlanarak omurgayı andıran bir form etkisi yaratır. Taş kütlelerin dış yüzeyleri de omurların yüzeylerine benzer strüktürel yapıya sahiptir.

Günümüz heykeltraşlarının canlı organizmaların iskelet formlarından ürettikleri onlarca örnek gösterilebilir. Bir bakıma bir çok çağdaş heykelin tasarımı, büyük ölçüde canlı organizmaların gözlenmesiyle elde edilmiştir. Doğa heykel sanatçıları için bir çok zenginliği içinde barındıran bir kaynaktır. 

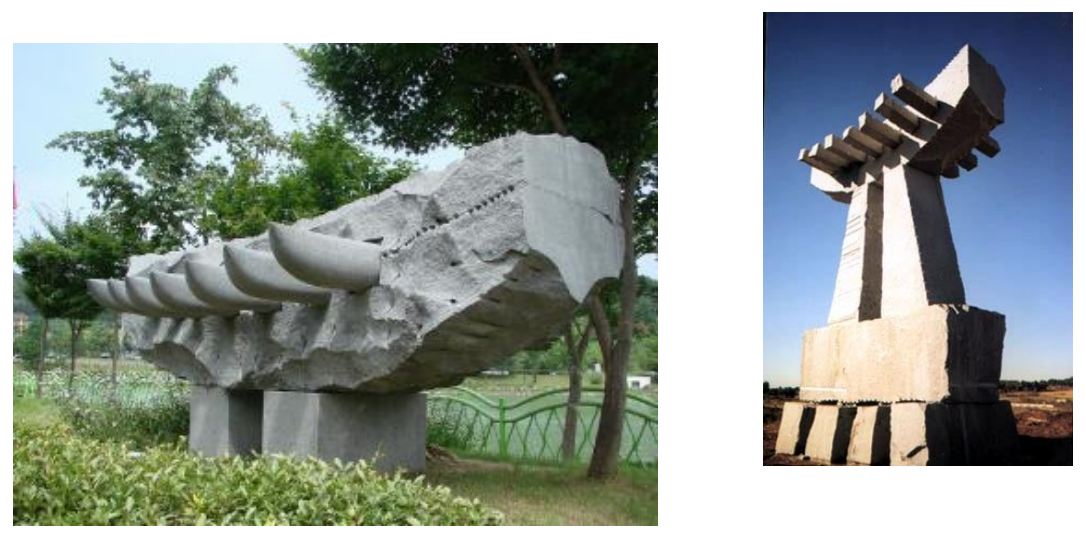

Görsel-16. Kemal Tufan,Icheon, Granit,Güney Kore,

Görsel-17. Kemal Tufan, alpalhao Bienal, Granit $599 X 250 X 200 \mathrm{~cm}$. Portekiz, 410X200X140cm.

\section{4-OMURGA VE MIMARI}

Mimari yapının formu ana omurga üzerinde biçimlendirilir. Tüm mimari unsurlar binanın omurgasına göre tasarlanır. Klasik yapıların omurga sistemi dönemin mimari anlayışına ve teknolojik imkanlarına göre tasarlanır. Örneğin, Ayasofya caminin omurgasını kubbeyi ayakta tutan sütunlar oluşturur. Bu sütunlar birbirine kolonlarla ve kemerlerle bağlanmıştır. Osmanlı klasik cami mimarisi aynı tasarım mantığına dayanır. Endüstri devrimi ile birlikte beton konstrüksiyonlar mimari yapılarda kullanılarak, binaların mimari tasarımı tamamen modüler sisteme göre biçimlendirilir. Çağdaş mimarinin temel yapısı omurga ve ona bağlı olan kaburgaları andıran bir sisteme sahiptir. Görsel-18'de olduğu gibi yapının katları sütun ve kolonlar üzerine oturtulmakta, iskelet sistemi biten yapı daha sonra örtücü malzemelerle giydirilmektedir. Günümüzde özgün tasarımlara sahip olan bir çok binanın tasarımı insan omurga sistemi örnek alınarak gerçekleştirilmiştir.

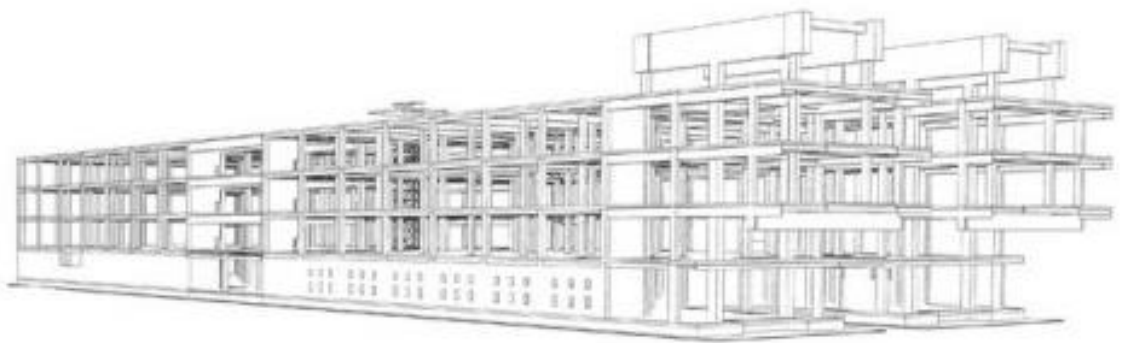


Görsel-18. Binanın iskeleti. Lab-Building-3D-BIM-Structural.

Örnekte görüldüğü gibi ‘SpineTower' iki, Design group tarafından 2008 yılında tasarlanan, Türkiye'nin çağdaş mimari örneklerinden biridir. Proje, iş kulelerinin yer aldığı Maslak'ta, kendine özgü tasarımı ve formuyla kent siluetine farklı açılardan katkı sunmaktadır (Görsel-19). Silindirik formu ile yumuşak bir duruşu olan SpineTower, köşeli ve net formdaki diğer yapılara göre kente her cephesinden açık, daha çekici bir dış forma sahiptir, bölgenin gözdesi niteliğindedir.Yapı, 47 katıyla ve 191 metreye ulaşan yüksekliğiyle İstanbul'un oldukça hareketli coğrafyasında hantal bir kule olarak yükselmek yerine, $360^{\circ}$ manzara özellikli dairesel formu ve kademeli yükselişi ile siluete kimlik katmaktadır. Projenin getirdiği yenilikçi yaklaşımlardan biri, binanın yükünü destekleyici dokunuşlarla dağıtan dış cephe öğeleridir. Omurga formundan esinlenerek tasarlanan yapı, etrafında yer alan kübik ve maskülen formların aksine feminen bir duruş sergilemektedir (ekoyapidergisi.org).

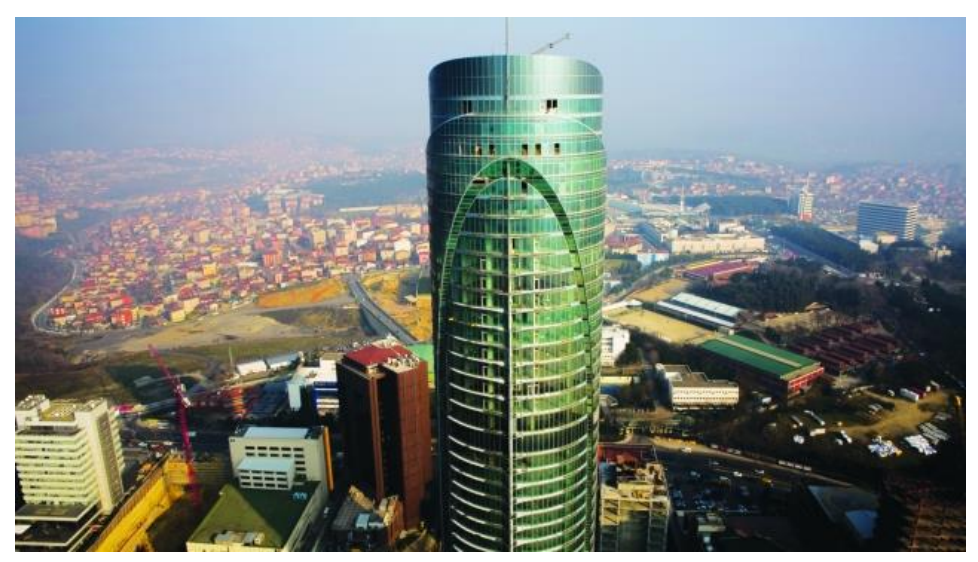

Görsel-19.SpineTower, İstanbul.

İsveç- Malmö de HSB Tuning Torso projesi mimar Santiago Calatrava tarafından tasarlanan spiral kule biçiminde yükselen bir yapıdır(Görsel 20). 1999 yılında, Santiago Calatrava, karışık kullanımlı bir kule yapmayı keşfedip, Malmö'nün Batı yakasındaki Liman alanında, hemen fark edilen bir yapı inşa etti. İsveç ile Danimarka'yı birbirine bağlayan en önemli köprülerden biri olan Oresund Köprüsü'nün çok yakınlarında bulunan proje, en önemli vizyon olarak taşıma sistemini belirlemiş. Eskimiş bir sanayi alanı olan Batı yakasındaki bu bölge, hızlı 
bir biçimde konut alanlarının, restoranların, alışveriş, merkezlerinin bulunduğu bir yerleşkeye dönüşmüş. HSB Turning Torso, 9 ayrı küp biçimindeki birimden oluşmuş. Bu ünitelerin her biri, 5 katlı konut birimlerini içerisinde bulunduruyor ve bu birimlerin her biri, yaklaşık olarak 2000 metre kare büyüklügünde ve küp biçimindeki birimlerin aralarında kalan boşluklar teknik işler için kullanılıyor. Binanın asıl biçimi, betondan yapılmış bir göbek etrafındaki çembersi formu daha da güçlendiriyor. Göbek kısmının içinin çap 1000 metre. Betonun kalınlığı ise, tabanda 250 metre olup, yukarıda 40 metreye kadar düşüyor ve göbekteki betonun içerisinde bir asansör ve merdivenler bulunuyor.
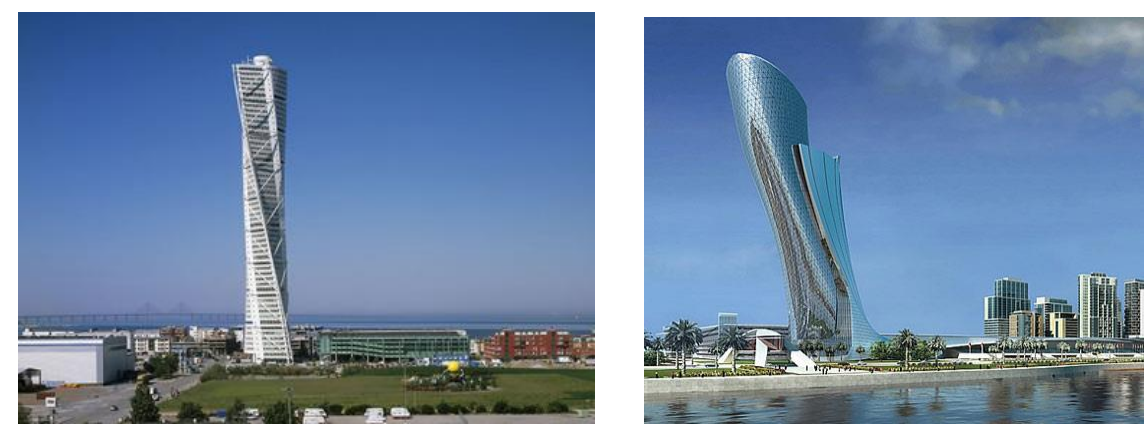

Görsel-20. Santiago Calatraya, HSB TurningTorso, Malmö, İsveç, 2005.

\section{Görsel-21.CapitalGate, Abu Dabi.}

Taşıyıcı göbeği güçlendiren unsur ise; parçalardan oluşan bir omurga gibi görev yapan, dış kısımdaki üçgenlerden oluşan takviye iskeleti. Bu omurga, yatay ve çapraz pek çok bağ ile küp şeklindeki ünitelerin her birine bağlanıyor. Omurga, ünitelerin her katına, küçük payandalarla bağlanmış. Dış cephe, yaklaşık 2800 kadar alüminyum panelden ve 2250 pencere camından oluşturulmuş ve her ünitede 300 panel bulunuyor. Dünyanın en eğik binası olarak bilinen Abu Dabi'deki "CapitalGate" adlı mimari yapı omurganın ' $S$ ' görünümünü andırmaktadır. $160 \mathrm{~m}$ yüksekliğinde olan bu binanın eğikliğinin 18 derece olduğu, bu eğikliği Pisa Kulesi’nin 4 katı kadar olduğu kaydedilmektedir (Görsel-21).

Görsel-22'de görülen ''Euroscraper" mimari yap1 jose Munos Viller tarafından tasarımlanmış olup Meksika'da yer almaktadır. Döngüsel bir tasarıma sahip olan binanın yapısal formu ilk bakışta canlı bir organizmanın kaburgasını 
hatırlatır. Tıpkı omurga ve kaburga sistemindeki modüler yapıda olduğu gibi. Bu binada döngüsel bir biçim tasarlanarak, iç ve dış mekanlarda doğa ile kurulan iletişim ön planda görülmektedir (Görsel-22).

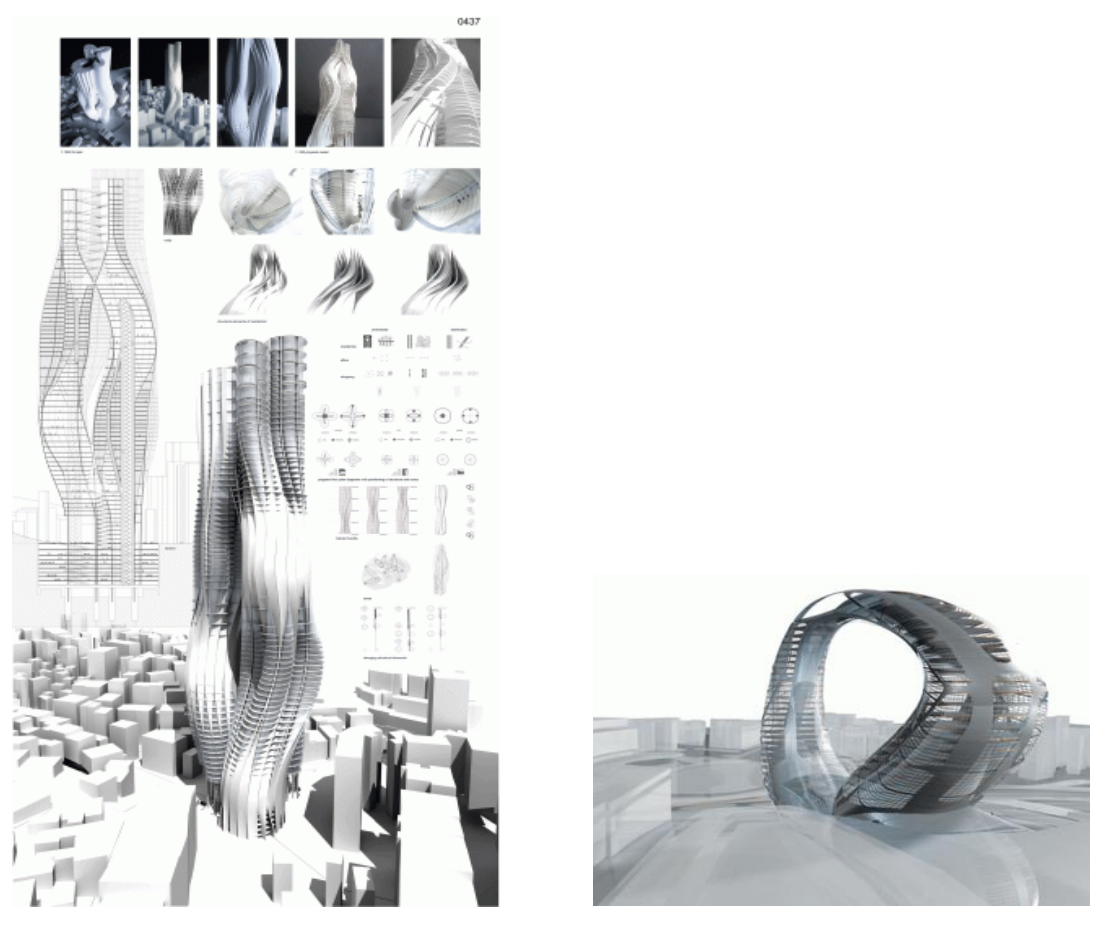

Görsel-22. JoseMonos-Viller,Euroscraper, 2007,Meksika.

Görsel-23'deki tasarım, bir mimari yarışma için hazırlanmıştır. Bir grup tasarımcı tarafından hazırlanan bu proje geleceğin şehir ve şehir binalarının tasarımının bir ön göstergesi olarak ortaya çıkmaktadır. Birincil yapı, "building tubular" sistem, yerden tepeye uzanan her biri merkezi bir çekirdek olan üç borudan oluşur. Sirkülasyonun birden fazla çekirdeğe dağıldığ 1 yerlerde iki tüp birleştirilir. İki tüp birleştiğinde, üçüncüsü bir merkezi çekirdekten bağımsız olarak kalır (böylece merkezi tipolojiyi korur). Kulede, her tüp diğer ikisi ile bir veya daha fazla noktada birbirine bağlanır. Tüpler birbirine sabitlendiğinden zemin plakaları binanın yüksekliğine rağmen nispeten küçük kalabilir(evolo.us). 


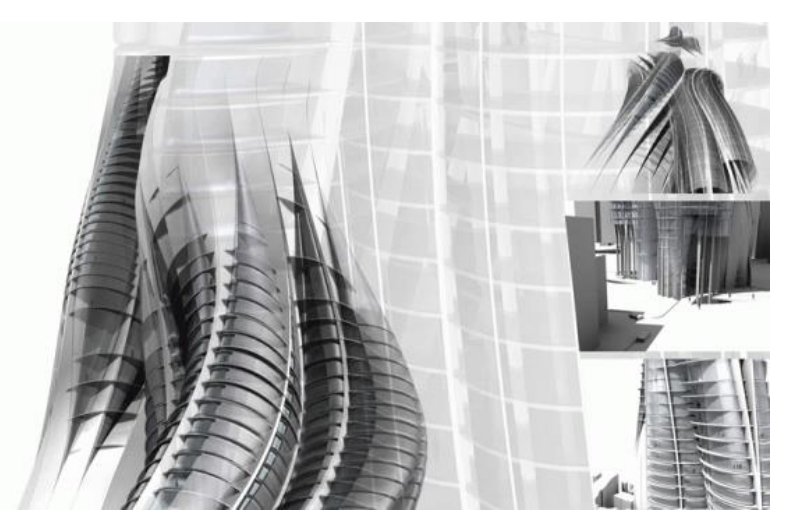

Görsel-22.SkyscraperCompetition,EldineHeep, GerhildOrthacker, JudithSchafelner, Elle Przybyla, 2007, Austria.

Mimari tasarımlarda olduğu gibi endüstriyel tasarımlarda da canlı organizmaların omurga sistemi üretilen araçlar için ilham kaynağı olmuştur. Görsel23'de verilen bir merdiven örneği tamamen omurga biçimini çağrıştırmaktadır. Omurganın biçimi açıkça görülmektedir. Görsel-24'deki geminin inşası ana omurga üzerinde tasarlanmakta ve geminin omurga sistemi canlı omurgalarının sistemi ile çok yakın benzerlik göstermektedir. Aynı şekilde, Görsel-25'deki uçağın ana omurga ve kaburga tasarımı canlı organizmaların omurga sistemine dayanmaktadır. Bütün uçakların aerodinamik yapıları kuşların anatomik yapıları ile benzerdir. Motorların ve pistonların tasarımları da omurga formlarına çok benzemektedirler. Görsel-26 ve $27^{\prime}$ 'deki piston ve motor örneklerinde açıkça görülebiliyor. 

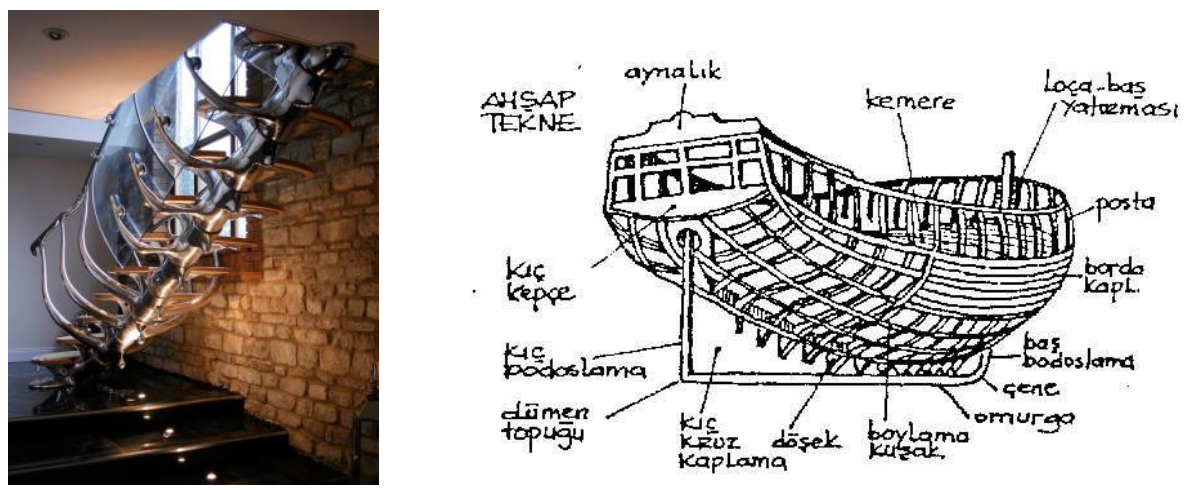

Görsel-23. Merdiven Tasarımı (Omurga Merdiven). Görsel-24. Gemi Tasarımı.
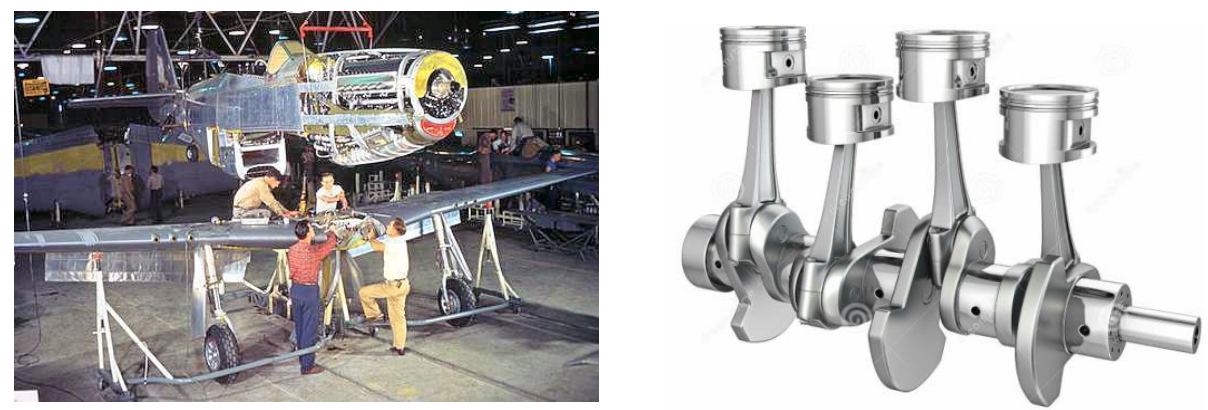

Görsel-25. Uçak Omurgası

Görsel-26. Pistonların Omurga Tasarımı

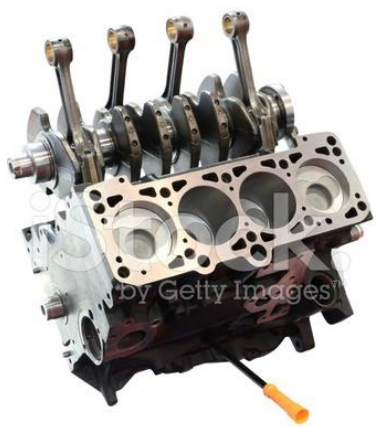

Görsel-27. Motorun Anatomik Tasarımı. 


\section{SONUÇ:}

$\mathrm{Bu}$ çalışmada sanat ve tasarım dalları arasında omurga mantığının "bir biçimlendirme sistemi" olarak nasıl kullanıldığı bir çok örnek üzerinde gösterilmiştir. Omurga sanatta organik bütünlüğü sağlayan önemli bir unsurdur. Her sanat eseri sağlam bir omurgaya sahiptir. Nasıl ki, canlı organizmalarda parçalar omurgayla ilişkili, omurgaya göre biçimlendirilmişlerse, bir tabloda renklerin plastizmi ve biçimler de tablonun ana omurgasına göre parça bütün ilişkisi içerisinde oluşturulmuştur. Resmin ana omurgasına aykırı olarak biçimlendirilen bir renk plastizmi ya da biçim resimde bütünlüğü bozar. Diğer sanat türlerinde de durum aynidır.

Omurganın modüler sistem özelliğindeki doğal yapısı insan bilimlerinde tasarım olgusunun da temelini oluşturmaktadır. Bu bağlamda omurga sisteminin sahip olduğu modüler özellikler sanat ve tasarım ürünlerin bir çoğunda benzer bir anlayışla kullanılmış, doğada var olan bu "biçimlenme sistemi" bir uçağın temel yapısından bir sandalyenin ayakta duruşuna kadar hemen hemen tüm tasarım ürünlerinde "bir biçimlendirme yöntemi" olarak kullanılmıştır.

\section{GÖRSEL LISTESİ:}

Görsel-1. Omurga ve Omur

Görsel-2. Leonardo-Da-Vinci Vinci, Vitruve, Luc, Viatour.

Görsel-3. Leonardo-Da-Vinci-Bones.

Görsel-4, 5. Leonardo Da Vinci, (sağ) Omur ve Omurga Çizimleri, (sol) İç Organların Naasıl Çalıştığını Gösteren Çizimleri

Görsel-6. Alex Trigals, Deep Spine, Akrilik, 2007.

Görsel-7. Sara Young, Spine, 2011, Akrilik.

Görsel-8. Noelle Rolli,Spine,

Görsel-9. Royal Mire, Spine, Suluboya, 2005, 30x30cm.

Görsel-10. Robert Sofian,The Spine of the Matter,Akrilik.

Görsel-11. HenriMoore

Görsel-12. Peter Kristiansen, GiantSpineSculpture

Görsel-13. SpineandPanels, Dovntown Art Guide, 1910. 
Görsel-14.Choe U-Ram, Guardian of the Hole, 2011, MetalikCalgary-Kanada Materyal, Reçine, Moto, Dişli, LED.

Görsel-15.U-Ram Choe, OpertusLunulaUmbra (HiddenShadow of Moon), 2008Bitforms Gallery

Görsel-16. Kemal Tufan,Icheon, Granit,Güney Kore,

Görsel-17. Kemal Tufan, alpalhao Bienal, Granit 599X250X200 cm. Portekiz, 410X200X140cm.

Görsel-18. Binanın iskeleti. Lab-Building-3D-BIM-Structural.

Görsel-19.SpineTower, İstanbul

Görsel-20. Santiago Calatraya, HSB TurningTorso, Malmö, İsveç, 2005.

Görsel-21.CapitalGate, Abu Dabi

Görsel-22. JoseMonos-Viller,Euroscraper, 2007,Meksika.

Görsel-22.SkyscraperCompetition,EldineHeep， GerhildOrthacker，JudithSchafelner， Elle Przybyla, 2007, Austria.

Görsel-23. Merdiven Tasarımı (Omurga Merdiven).

Görsel-24. Gemi Tasarımı.

Görsel-25. Uçak Omurgası

Görsel-26. Pistonların Omurga Tasarımı

Görsel-27. Motorun Anatomik Tasarımı

\section{KAYNAKÇA}

YAVUZ, A. F. ( ) Kur'an- kerim ve Türkçe meali, Bakara, 2/29. s.139-140.

MARCH, J. (2001). Cassell'sdictionary of classicalmythology, Cassell\&Co,

RAVLING, A. (2008). Tokyo's urban parasites", Tokyo Art Beat, Jun 09. http://www.tokyoartbeat.com/tablog/entries.en/2008/06/tokyos-urban-parasites.html, 16.03.2017.

YAVUZ, A. F. ( ) Kur'an- kerim ve Türkçe meali, Tin, 95/4. 
YILMAZ, O. (2016). “Modern heykelde soyutlaşan beden İmgeler”, İstanbul: MSKU Eğitim Fakültesi Dergisi, C.3, s.53, Nisan.

\section{İnternet Kaynakları:}

http://asiasociety.org/blog/asia/video-u-ram-choes-mesmerizing-animatronicsculpture-guardian-hole, 15.03.2017.

http://www.ekoyapidergisi.org/1036-omurga-formundan-esinlenen-feminen-birdurus.html, 17.03.2017.

http://www.evolo.us/competition/compressed-complexity/ 16.03.2017.

U-Ram Choe'swebsite. 15.03.2017. 